\title{
Analiza postaw młodzieży wobec transplantacji narządów
}

\section{Analysis of attitudes of young people towards organs transplantation}

\author{
MARZENA HUMAŃSKA ${ }^{1}$ KATARZYNA MICHALINA DUDEK ${ }^{1}$ \\ ${ }^{1}$ Pracownia Podstaw Umiejętności Klinicznych i Symulacji Medycznej, CM im. L. Rydygiera \\ w Bydgoszczy UMK w Toruniu
}

DOI: http://dx.doi.org/10.21784/IwP.2017.004

ISSN: 2451-1846

\section{Streszczenie:}

Wstęp. Transplantacja jest to zabieg operacyjny, polegający na przeszczepieniu osobie chorej narządu/ów, tkanek lub komórek pobranych od innej osoby lub zwierzęcia. Zapotrzebowanie na przeszczepy ma nadal tendencję wzrostową, natomiast podaż narządów jest wciąż niewystarczająca. Istotnym problemem na całym świecie jest pozyskiwanie możliwych dawców. Obecnie poglądy etyczne oraz przekonania religijne dotyczące transplantacji narządów budzą wiele kontrowersji i dyskusji.

Cel. Celem badań była analiza postaw młodzieży w zakresie transplantacji narządów.

Materiał i metody. Badania zostały przeprowadzone w Zespole Szkół Ponadgimnazjalnych nr $1 \mathrm{im}$. Jana Pawła II w Inowrocławiu oraz w Zespole Szkół Ponadgimnazjalnych im. Jana Pawła II w Kościelcu. Grupę badawczą stanowiło 120 osób. Do analizy badań wykorzystano ankietę własnej konstrukcji. Zastosowano parametryczne i nieparametryczne testy istotności w celu weryfikacji postawionych hipotez. Na przeprowadzenie badań uzyskano zgodę Komisji Bioetycznej przy Collegium Medicum im L. Rydygiera w Bydgoszczy UMK w Toruniu (KB/347/2011). 
Wyniki. Analizowane badania ukazują istotną różnice między częstością odpowiedzi „Tak” i „Nie”. Z przeprowadzonych badań wynika iż, 90,0\% respondentów akceptuje pobieranie narządów od osób zmarłych oraz 93,3 \% wśród badanych w sytuacji zagrożenia życia i konieczności wykonania przeszczepu przyjęłaby cudzy narząd. Ankietowani w 70,8 \% byliby gotowi do bycia dawcą tkanki lub narządu parzystego za życia. Natomiast $75 \%$ $\mathrm{z}$ nich zgodziłaby się, aby po ich śmierci pobrano jakiś narząd w celu przeszczepienia go innej osobie. W ocenie badanych 80,8 \% uważa, że wiedza społeczeństwa na temat transplantacji nie jest wystarczająca, a 88,3 \% uważa, iż większa świadomość społeczeństwa na temat transplantacji może mieć wpływ na liczbę przeszczepów.

Wnioski. 1. Badana młodzież osobiście akceptuje pobranie narządów od osób zmarłych. 2. Młodzież uważa, że w sytuacji zagrożenia życia i konieczności wykonania przeszczepu przyjęłaby cudzy narząd. 3. Badana młodzież byłaby gotowa do bycia dawcą tkanki lub narządu parzystego za życia. 4. Młodzież zgodziłaby się, aby po ich śmierci pobrano od nich jakiś narząd w celu przeszczepienia go innej osobie. 5. Młodzież uważa, że wiedza społeczeństwa na temat transplantacji nie jest wystarczająca. 6. Badana młodzież uważa, że większa świadomość społeczeństwa na temat transplantacji może mieć wpływ na liczbę przeszczepów.

Słowa kluczowe: transplantacja, postawa, narząd, dawca

\section{Abstract:}

Introduction. Transplantation is a surgical procedure during which the ill person receives as in form of transplant theorgan(s), tissues or cells taken from another person or animal. The demand for transplants has been continuously on the rise; still the supply of organs is insufficient. An important world problem is to attract potential donors. Currently, ethical views and religious beliefs relating to organ transplantation have triggered a lot of controversy and provoked numerous debates.

Aim. The aim of the study was to analyze the stance of young people on organ transplantation procedures.

Material and methods. The study was conducted at the School Complex No. 1 named after Pope John Paul II [Zespół Szkół Ponadgimnazjalnych nr $1 \mathrm{im}$. Jana Pawła II],in Inowrocław, and the Complex of Secondary Schools named after Pope John Paul II [Zespół Szkół Ponadgimnazjalnych im. Jana 
Pawła II] in Kościelec. The group researched upon consisted of 120 people. A questionnaire developed by the paper's author was used for the purpose of collecting data and their respective analysis. Furthermore, parametric and non-parametric tests of significance were conducted in order to verify the already supported hypotheses. The survey had been primarily approved of by the Bioethics Committee of the Medical College named after L. Rydygiera in Bydgoszcz, and the Nicolaus Copernicus University in Torun.

Results. The study results indicate that $90.0 \%$ of respondents approve oforgansprocurement from deceased people; what is more, the $93.3 \%$ of respondentsif placed in life-threatening situation and theneed of transplantation - would agree to receive someone else's organ.70.8\% of respondents would be willing to be donors of any tissue or an even organ during their life. At the same time $75 \%$ of survey participants would agree to have their organ substracted after their death so that it might be transplanted to any other alive person in need. According to $80 \%$ of respondents, the knowledge on transplantation held by society members is not enough. $88.3 \%$ of respondents, however, believe that any bigger public awareness of transplantation may affect the quantity of transplantations.

Conclusions. 1 . The young people accept organ donation from deceased people. 2. The young people claim that in life-threatening situations and if in need of transplantation they would approve of having another person's organ transplanted into their body. 3. The researched young people would be willing, during their life, to be donors of any tissue or any even organ. 4. Young people agree to have, after their death, their organs transplanted to another person. 5. Young people believe that public knowledge of transplantation is not enough. 6 . The researched young people believe that bigger public awareness of transplantation may affect the quantity of transplantations.

Keywords: transplantation, attitude, organ, donor

\section{Wstęp}

Transplantacja od łacińskiego słowa „transplantare” co oznacza szczepić, przesadzać, przenosić. Jest to zabieg operacyjny, który polega na przeszczepieniu osobie chorej narządu/ów, tkanek lub komórek 
pobranych od innej osoby lub zwierzęcia. Przeszczepianie wykorzystuje się $w$ celach leczniczych i diagnostycznych, ale także naukowych i dydaktycznych. Podejmuje się ryzyko nie przyjęcia się danego organu, mimo, że tego typu zabiegi są skomplikowane oraz pracochłonne. Może okazać się, że wszczepiony organ może być potraktowany jako ciało obce i organizm będzie próbował go zwalczyć (odrzucenie przeszczepu) [1,2].

Przeszczep to narząd lub tkanka, który jest pobrany od dawcy w celu zastąpienia brakującego lub uszkodzonego organu, tkanki poprzez chirurgiczne przeszczepienie do organizmu biorcy. Niektóre narządy i tkanki są konserwowane a potem przechowywane $\mathrm{w}$ tak zwanych bankach $[3,4,5]$.

Badając temat przeszczepów należy wyjaśnić podstawowe pojęcia, które ściśle związane są z transplantacją. Dawca jest to osoba żywa lub zmarła od której pobiera się narząd, tkankę lub komórki w celu przeszczepienia go innej osobie. Biorca jest to osoba, której wszczepia się potrzebujący narząd, tkanki lub przetacza się krew od dawcy $[6,7]$.

Zapotrzebowanie na przeszczepy ma nadal tendencję wzrostową, natomiast podaż narządów jest wciąż niewystarczająca. Istotnym problemem na całym świecie jest pozyskiwanie możliwych dawców. Względy kulturowe, organizacyjne oraz medialne przyczyniły się do zmniejszenia liczby donacji w kilku ostatnich latach. Transplantacja narządów jest metodą, która ratuje ludzkie życie. Chory potrzebuje zdrowego narządu, aby mógł dalej cieszyć się życiem $[3,8,9]$.

Obecnie poglądy etyczne oraz przekonania religijne dotyczące transplantacji narządów budzą wiele kontrowersji i dyskusji [10]. Medycyna transplantacyjna jest wyjątkową formą leczenia, zdobywająca coraz szersze grono badaczy. Stanowi jedną z wielu specjalności medycznych, która związana jest z licznymi problemami natury etycznej i moralnej [11]. Przyszłość rozwoju transplantologii 
w znacznej mierze zależy od poziomu akceptacji społecznej oraz gotowości pomocy drugiemu człowiekowi.

\section{Materiał i metody}

Badania przeprowadzono w Inowrocławiu w Zespole Szkół Ponadgimnazjalnych nr $1 \mathrm{im}$. Jana Pawła II oraz w Zespole Szkół Ponadgimnazjalnych im. Jana Pawła II w Kościelcu. Ankietowani zostali tylko uczniowie, którzy wyrazili pisemną zgodę na udział w tych badaniach. Każdy respondent został poinformowany o celu badań oraz ich naukowym charakterze. Na przeprowadzenie badań uzyskano zgodę Komisji Bioetycznej przy Collegium Medicum im. L. Rydygiera w Bydgoszczy UMK w Toruniu (KB/347/2011). Analizę statystyczną przeprowadzono przy użyciu programu statystycznego SPSS Statistics oraz Excel. Zastosowano testy istotności parametryczne i nieparametryczne w celu weryfikacji postawionych hipotez.

\section{Wyniki}

Badanym zaproponowano wybór jednej odpowiedzi z następujących: „Tak”, „Raczej tak”, „Nie”, „Raczej nie” oraz „Nie wiem”. Odpowiedzi „Tak” i „Raczej tak” oraz „Nie” i „Raczej nie” były zgrupowane jako odpowiedzi stwierdzające i odrzucające. Następnie policzono liczebności i procenty tych odpowiedzi. Zastosowano parametryczny test dla dwóch frakcji w celu porównania procentów (częstości) występowania odpowiedzi pozytywnych i negatywnych (pomijając odpowiedzi „Nie wiem”). Wartość krytyczna przy poziomie istotności $p=0.05$ wynosi 1.96 .

Tabela 1. Ocena badanych dotycząca akceptacji pobrania narządów od osób zmarłych $w$ celu leczenia i ratowania życia osobom chorym. 


\begin{tabular}{|l|l|l|l|}
\hline $\begin{array}{l}\text { Czy Pan(i) osobiście akceptuje } \\
\text { pobieranie narządów od osób } \\
\text { zmarłych, w celu leczenia i }\end{array}$ & $n$ & $\%$ \\
$\begin{array}{l}\text { ratowania życia osobom } \\
\text { chorym? }\end{array}$ & 108 & $90.0 \%$ \\
\hline \hline Tak i raczej tak & 5 & $4.2 \%$ \\
\hline Nie i raczej nie & 7 & $5.8 \%$ \\
\hline Nie wiem & $u$ & 13.3 \\
\hline \hline Test dla 2-ch frakcji & $p$ & $<0.0001$ \\
\hline
\end{tabular}

Źródło: wyniki badań własnych

Tabela 1 obrazuje analizę postawy młodzieży wobec transplantacji narządów. Z analizy wynika że akceptacja młodzieży wobec transplantacji narządów jest istotna statystycznie, ponieważ poziom $\mathrm{p}<0,0001$.

Z danych wynika iż 90,0 \% respondentów akceptuje pobieranie narządów od osób zmarłych, 4,2 \% osób jest przeciwna wobec pobierania narządów od osób zmarłych, a 5,8\% osób nie ma zdania na ten temat.

Analizując wyniki testowania można stwierdzić, że zdecydowana większość uczniów osobiście akceptuje pobieranie narządów od osób zmarłych w celu leczenia i ratowania życia osobom chorym.

Tabela 2. Ocena badanych dotycząca przyjęcia cudzego narządu w sytuacji zagrożenia życia i konieczności wykonania przeszczepu. 


\begin{tabular}{|c|c|c|c|}
\hline \multicolumn{2}{|c|}{$\begin{array}{l}\text { Czy w } \\
\text { życia i konieczności } \\
\text { wykonania progrożenia } \\
\text { przyjąłby(przyjęłaby) } \\
\text { Pan(i) cudzy narząd? }\end{array}$} & $n$ & $\%$ \\
\hline \multicolumn{2}{|l|}{ Tak i raczej tak } & 112 & $93.3 \%$ \\
\hline \multicolumn{2}{|l|}{ Nie i raczej nie } & 3 & $2.5 \%$ \\
\hline \multicolumn{2}{|l|}{ Nie wiem } & 5 & $4.2 \%$ \\
\hline \multirow{2}{*}{ Test dla 2-ch frakcji } & $u$ & \multicolumn{2}{|c|}{14.1} \\
\hline & $p$ & \multicolumn{2}{|c|}{$<0.0001$} \\
\hline
\end{tabular}

Źródło: wyniki badań własnych

Tabela 2 obrazuje ocenę zachowania respondentów wobec transplantacji narządów. Z powyższej analizy wynika, że młodzież w sytuacji zagrożenia życia i konieczności wykonania przeszczepu przyjęłaby cudzy narząd. Są to dane istotne statystycznie, ponieważ poziom $\mathrm{p}<0,0001$.

$\mathrm{Z}$ danych wynika, iż 93,3 \% ankietowanych w sytuacji zagrożenia życia i konieczności wykonania przeszczepu przyjęłaby cudzy narząd , 2,5 \% osób nie przyjęłaby cudzego narządu w sytuacji zagrożenia życia, a $4,2 \%$ osób nie wie jak postąpiłaby w danej sytuacji. Wykonując analizę wyników testowania można stwierdzić, że zdecydowana większość uczniów w sytuacji zagrożenia życia i konieczności wykonania przeszczepu przyjęłaby cudzy narząd.

Tabela 3. Ocena dotycząca gotowości badanych do bycia dawcą tkanki lub narządu parzystego za życia.

\begin{tabular}{|l|l|l|l|}
\hline Czy był(a)by Pan(i) gotowy(a) & & \\
do bycia dawcą tkanki lub & $n$ & $\%$ \\
narządu parzystego za życia? & & \\
\hline
\end{tabular}




\begin{tabular}{|c|c|c|c|}
\hline Tak i raczej tak & & 85 & $70.8 \%$ \\
\hline Nie i raczej nie & & 3 & $2.5 \%$ \\
\hline Nie wiem & & 32 & $26.7 \%$ \\
\hline & $u$ & 11. & \\
\hline & $p$ & $<0$. & \\
\hline
\end{tabular}

Źródło: wyniki badań własnych

Tabela 3 obrazuje analizę z której wynika, że większość ankietowanych byłaby gotowa do bycia dawcą tkanki lub narządu parzystego za życia . To dane istotne statystycznie, ponieważ poziom $\mathrm{p}<0,0001$.

Przeprowadzone badania wskazują, iż 70,8 \% ankietowanych byłaby gotowa do bycia dawcą tkanki lub narządu parzystego za życia, 2,5 \% osób nie byłaby gotowa do bycia dawcą tkanki lub narządu parzystego za życia, a $26,7 \%$ osób nie wie jak postąpiłaby w danej sytuacji.

Natomiast między częstościami odpowiedzi „Tak” i „Nie” została wykryta istotna różnica. Analizując wyniki testowania można stwierdzić, że zdecydowana większość uczniów byłaby gotowa do bycia dawcą tkanki lub narządu parzystego za życia.

Tabela 4. Ocena dotycząca zgody ankietowanych na pobranie narządów po śmierci.

\begin{tabular}{|l|l|l|}
\hline $\begin{array}{l}\text { Czy zgodził(a)by się Pan(i), aby } \\
\text { po Pana(i) śmierci pobrano od } \\
\text { Pana(i) jakiś narząd w celu jego }\end{array}$ & $n$ & $\%$ \\
przeszczepienia?
\end{tabular}




\begin{tabular}{|l|l|l|}
\hline Tak i raczej tak & 90 & $75.0 \%$ \\
\hline Nie i raczej nie & 7 & $5.8 \%$ \\
\hline Nie wiem & 23 & $19.2 \%$ \\
\hline \hline \multirow{2}{*}{ Test dla 2-ch frakcji } & $u$ & 10.9 \\
\cline { 2 - 3 } & $p$ & $<0.0001$ \\
\hline
\end{tabular}

Źródło: wyniki badań własnych

Tabela 4 obrazuje analizę z której wynika, że większość ankietowanych zgodziłaby się, aby po ich śmierci pobrano jakiś narząd w celu przeszczepienia go innej osobie. To dane istotne statystycznie, ponieważ poziom $\mathrm{p}<0,0001$.

$\mathrm{Z}$ przedstawionych $\mathrm{w}$ tabeli danych wynika, iż 75,0 \% respondentów zgodziłaby się, aby po ich śmierci pobrano jakiś narząd w celu przeszczepienia go innej osobie, 5,8 \% osób nie zgodziłaby się, aby po ich śmierci pobrano jakiś narząd w celu przeszczepienia go innej osobie, a 19,2\% osób nie wie jak postąpiłaby w danej sytuacji.

$\mathrm{Na}$ podstawie wyników testowania można stwierdzić, że zdecydowana większość ankietowanych zgodziłaby się, aby po ich śmierci pobrano jakiś narząd w celu przeszczepienia go innej osobie.

Tabela 5. Ocena respondentów dotycząca wiedzy społeczeństwa na temat transplantacji.

\begin{tabular}{|llr|l|l|}
\hline \hline Czy według & Pana(i) & wiedza & & \\
społeczeństwa na & temat & $n$ & $\%$ \\
transplantacji & jest & & \\
wystarczająca? & & & \\
\hline Tak i raczej tak & & 13 & $10.8 \%$ \\
\hline
\end{tabular}




\begin{tabular}{|l|l|l|l|}
\hline Nie i raczej nie & 97 & $80.8 \%$ \\
\hline Nie wiem & 10 & $8.3 \%$ \\
\hline \hline \multirow{2}{*}{ Test dla 2-ch frakcji } & $U$ & 11.0 \\
\cline { 2 - 3 } & $P$ & $<0.0001$ \\
\hline
\end{tabular}

Źródło: wyniki badań własnych

Tabela 5 obrazuje analizę z której wynika, że większość ankietowanych uważa, iż wiedza społeczeństwa na temat transplantacji nie jest wystarczająca. To dane istotne statystycznie, ponieważ poziom $\mathrm{p}<0,0001$.

Przedstawione wyniki wskazują, iż 80,8 \% ankietowanych uważa, że wiedza społeczeństwa na temat transplantacji nie jest wystarczająca, 10,8 \% osób uważa, że wiedza społeczeństwa jest wystarczająca, a 8,3 \% osób nie wie czy wiedza społeczeństwa jest wystarczająca.

Poddając analizie przeprowadzone badania można stwierdzić, że zdecydowana większość ankietowanych uważa, że wiedza społeczeństwa na temat transplantacji nie jest wystarczająca.

Tabela 6. Ocena ankietowanych dotycząca wpływu świadomości społeczeństwa na temat transplantacji na liczbę przeszczepów.

\begin{tabular}{|c|c|c|}
\hline $\begin{array}{l}\text { Czy uważa Pan(i), że większa } \\
\text { świadomość społeczeństwa na } \\
\text { temat transplantacji może mieć } \\
\text { wpływ na liczbę przeszczepów? }\end{array}$ & $n$ & $\%$ \\
\hline Tak i raczej tak & 106 & $88.3 \%$ \\
\hline
\end{tabular}




\begin{tabular}{|l|l|l|l||}
\hline \multicolumn{2}{|l|}{ Nie i raczej nie } & 6 & $5.0 \%$ \\
\hline Nie wiem & 8 & $6.7 \%$ \\
\hline \hline \multirow{2}{*}{ Test dla 2-ch frakcji } & $U$ & 12.9 \\
\cline { 2 - 4 } & $P$ & $<0.0001$ \\
\hline
\end{tabular}

Źródło: wyniki badań własnych

Tabela 6 obrazuje analizę z której wynika, że młodzież uważa, iż większa świadomość społeczeństwa na temat transplantacji może mieć wpływ na liczbę przeszczepów. To dane istotne statystycznie, ponieważ poziom $\mathrm{p}<0,0001$.

$\mathrm{Na}$ podstawie badań stwierdza się, iż 88,3 \% ankietowanych uważa, iż większa świadomość społeczeństwa na temat transplantacji może mieć wpływ na liczbę przeszczepów, 5,0 \% osób uważa, że większa świadomość społeczeństwa na temat transplantacji nie może mieć wpływu na liczbę przeszczepów, a 6,7 \% osób nie wie czy większa świadomość społeczeństwa na temat transplantacji może mieć wpływ na liczbę przeszczepów.

Między częstościami odpowiedzi „Tak” i „Nie” została wykryta istotna różnica. Analizując wyniki testowania można stwierdzić, że zdecydowana większość badanych uważa, że większa świadomość społeczeństwa na temat transplantacji może mieć wpływ na liczbę przeszczepów.

\section{Dyskusja}

W badaniach własnych wykazano, iż ankietowani akceptują pobranie narządów od osób zmarłych. Taką akceptację zadeklarowało aż 90\% respondentów. Przeprowadzone badania własne potwierdzają także inni autorzy. Z raportu badań ISPSOS opracowany przez Kośmider-Cichomską A. wynika, iż zdecydowana większość Polaków czyli 78\% w wieku 15 lat i więcej w sposób jednoznaczny lub z pewnym wahaniem, akceptuje pobieranie narządów od zmarłych 
w celu leczenia i ratowania życia osobom chorym. Studenci uczelni medycznych w 82\% odpowiedzieli, że zdecydowanie akceptują pobieranie narządów od osób zmarłych, trochę mniej czyli w 82\% potwierdzili to lekarze, następnie $65 \%$ pielęgniarki oraz $64 \%$ studenci uczelni pozamedycznych. Najmniejszy odsetek odnotowano w próbie ogólnopolskiej - 39\%. Zarówno lekarze jak i studenci medycyny w większości w sposób jednoznaczny i zdecydowany opowiadają się za pobieraniem narządów od osób zmarłych i wyróżniają się pod tym względem na tle pozostałych badanych grup [12].

Praca badawcza Makary-Studzińskiej M. i wsp. wskazuje na to, iż ideę transplantacji narządów popiera więcej pielęgniarek z wyższym wykształceniem, niż $\mathrm{z}$ wykształceniem średnim. Pielęgniarek akceptujących tą ideę $\mathrm{z}$ wykształceniem licencjackim i średnim było $86 \%$ i $80 \%$. Z kolei pielęgniarki z wykształceniem średnim w 22\% były przeciwne tej kwestii [13].

W badaniach przeprowadzonych przez Pietruszkę M. oraz Falkowską-Pijagin E. wykazano, iż większość pielęgniarek i lekarzy tj. 96\% osobiście akceptuje pobieranie narządów od osób zmarłych w celu ratowania zdrowia i życia osób chorych [14].

Z danych Centrum Badania Opinii Społecznej (wyniki opracowania Derczyńskiego $\quad$ W.) wskazują, iż 87\% polskiego społeczeństwa akceptuje przeszczepianie narządów pobranych od osób zmarłych i uważa to za słuszne, w tym $62 \%$ osób potwierdziło to w sposób zdecydowany. Tylko niewielka grupa badanych -7\% - nie aprobuje tej metody leczenia [15]. Także w pracy Majchrowicz B. i Sadowskiej L. mieszkańcy Podkarpacia w 80\% akceptują pobieranie narządów od osób zmarłych [16]. Według badań Szczepańskiego S. i Pawlicy B. mieszkańcy województwa śląskiego akceptują pobieranie narządów od osób zmarłych - 86\% ogółu badanych (53\% zdecydowanie tak, 33\% raczej tak) [17]. Gorzkiewicz B. i wsp. badali postawy młodzieży dotyczące transplantacji w zależności od typów studiów. Stopień akceptacji był zróżnicowany. Najwyższym stopniem akceptacji pobierania narządów wykazali się 
studenci kierunków medycznych. Gorzkiewicz B. i wsp. odnotowali, iż poziom akceptacji jest wyższy wśród ludzi młodych i lepiej wykształconych [18]. Z badań Borkowskiej B. i Falkowskiej-Pijagin E. wynika, że 56\% ankietowanych uważa za słuszne pobieranie od osób zmarłych w celu ratowania życia lub przywracania zdrowia, a 29\% respondentów częściowo popiera te metodę leczenia [19].

Badania własne oraz innych autorów potwierdzają, że w społeczeństwie $\mathrm{z}$ biegiem lat wzrasta akceptacja wobec transplantacji narządów. Analizując przeprowadzone badania można stwierdzić, iż w sytuacji zagrożenia swojego życia i konieczności wykonania przeszczepu, młodzież przyjęłaby cudzy narząd. Z opracowań Borkowskiej B. i Falkowskiej-Pijagin E. wynika, że 89\% respondentów w sytuacji zagrożenia życia i konieczności dokonania przeszczepu, przyjęłaby narząd $\mathrm{w}$ celu ratowania swojego życia, w tym $21 \%$ wyraziłaby zgodę na przyjęcie narządu tylko od osoby spokrewnionej [19].

Można także stwierdzić, że młodzież zna cenę życia ludzkiego i akceptuje chęć przyjęcia narządu od innego, niespokrewnionego dawcy. Przeprowadzone badania wykazały, iż ankietowani byliby gotowi do bycia dawcą tkanki lub narządu parzystego za życia. W ocenie badań Gorzkiewicz B. i wsp. odnotowano, że aż $97 \%$ respondentów byłaby gotowa oddać nerkę za życia osobie spokrewnionej lub bliskiej. Odnotowano także, że oddanie nerki budzi najmniej emocji [18]. Z tych wyników Borkowskiej B. i FalkowskiejPijagin E. można odczytać, że ponad połowa respondentów tj. 53\% w pełni akceptuje pobierania i przeszczepianie tkanek i narządów za życia, a częściowo popiera $34 \%$ badanych [19]. Praca badawcza Makary-Studzińskiej M. i wsp. wykazała, że w grupie respondentek, które zgodziły się na oddanie swoich narządów po śmierci, w sytuacji oddania narządu za życia chęć oddania wyraziło 100\% badanych osób, z czego 44\% tylko osobie bliskiej [13]. W analizie przeprowadzonych badań przez Pietruszkę M. oraz Falkowską-Pijagin E. w 56\% osoby ankietowane byłyby gotowe oddać swój narząd za życia [14]. Wg 
analizy Szczepańskiego S. i Pawlicy B. wśród ankietowanych mieszkańców województwa śląskiego $60 \%$ zadeklarowało pomoc osobie z najbliższej rodziny, $38 \%$ przyjacielowi a $29 \%$ obcej osobie [17].

Badania własne wykazały, iż ankietowani zgodziliby się, aby po ich śmierci pobrano od nich jakiś narząd w celu przeszczepienia go innej osobie. Z badań Borkowskiej B. i Falkowskiej-Pijagin E. wynika, że trzy czwarte respondentów tj. 75\% wyraziłoby zgodę na oddanie narządów [19]. Także w pracy Majchrowicz B. i Sadowskiej L. ponad $80 \%$ ankietowanych akceptowało pobieranie narządów po śmierci i deklarowało donacje własnych [16]. Z danych Centrum Badania Opinii Społecznej (opracowanie Derczyńskiego W.) wynika, że 74\% Polaków wyraziłoby zgodę na pobranie od nich narządów po śmierci w celu przeszczepienia osobom potrzebującym [15]. Z badań MakaryStudzińskiej M. i wsp. wynika, iż 73\% respondentek jest zdecydowana na oddanie narządów po śmierci [13]. W badaniach przeprowadzonych przez Pietruszkę M. oraz Falkowską-Pijagin E.76\% osób badanych byłaby gotowa do oddania swoich narządów po śmierci [14].

W niniejszej pracy wykazano także, iż młodzież uważa, że wiedza społeczeństwa na temat transplantacji nie jest wystarczająca. Z opracowanych badań Borkowskiej B. i Falkowskiej-Pijagin E. wynika, że aż 89\% ankietowanych uważa, iż społeczeństwo mało wie na temat przeszczepów. Z opinii respondentów wiedza społeczeństwa na temat transplantacji narządów jest niska [19].

Badania własne wykazały, iż w ocenie uczniów większa świadomość społeczeństwa na temat transplantacji może mieć wpływ na liczbę przeszczepów. W badaniach Borkowskiej B. i FalkowskiejPijagin E. 92\% respondentów uważa, iż większa świadomość społeczeństwa na temat transplantacji narządów, może mieć wpływ na liczbę przeszczepów, a $81 \%$ badanych uważa, że kształtowanie świadomości społecznej sprzyja postawie dawcy [19].

\section{Wnioski}


1. Badana młodzież akceptuje pobranie narządów od osób zmarłych.

2. Młodzież uważa, że w sytuacji zagrożenia życia i konieczności wykonania przeszczepu przyjęłaby cudzy narząd.

3. Badana młodzież byłaby gotowa do bycia dawcą tkanki lub narządu parzystego za życia.

4. Młodzież zgodziłaby się, aby po ich śmierci pobrano od nich jakiś narząd w celu przeszczepienia go innej osobie.

5. Młodzież uważa, że wiedza społeczeństwa na temat transplantacji nie jest wystarczająca.

6. Badana młodzież uważa, że większa świadomość społeczeństwa na temat transplantacji może mieć wpływ na liczbę przeszczepów.

\section{Zalecenia dla praktyki pielęgniarskiej}

Jakość opieki świadczona w placówkach medycznych wykonujących zabiegi transplantacyjne wynika między innymi z kwalifikacji kadry, w tym zespołu pielęgniarek, który posiada umiejętności rozmowy z rodziną i pacjentami o przeszczepie, dając wyraz zindywidualizowanego podejścia do problemów podopiecznych.

\section{Bibliografia/Bibliography:}

1. Tokarczyk R.: Prawa narodzin, życia i śmierci. Podstawy biojurysprudencji. Wydawnictwo Oficyna Wolters Kluwer Polska Sp. z o.o. Warszawa. 2009;214-232.

2. Guzik-Makaruk E.M.: Transplantacja organów, tkanek i komórek w ujęciu prawnym i kryminologicznym. Wydawnictwo Termida 2. Białystok. 2008;2566.

3.http://www.zdrowie.abc.com.pl/czytaj/-/artykul/cywilnoprawny-aspekttransplantacji-organow, 28.02.2017, godz. 17.15. 
4. http://www.zgapa.pl/zgapedia/Transplantacja.html, 28.02.2017, godz. 23.15 .

5. http://www.transplantacja.org.pl/pytania.php, 28.02.2017, godz.23.25.

6. http://sjp.pwn.pl/szukaj/przeszczep, 28.02.2017, godz. 23.40.

7. http://www.iss.it/binary/ecet/cont/slownik.1194360764.pdf,28.02.2017, godz. 22.50 .

8. Kruszyński Z.: Intensywna terapia stanu astmatycznego. Przygotowanie dawcy narządów. Wydawnictwo Lekarskie PZWL. Warszawa. 2009;55-59.

9. Olszewski W.L.: Międzygatunkowe przeszczepianie tkanek i narządów (ksenotransplantacje) problemy biologiczne i kliniczne. W: Transplantologia kliniczna. Rowiński W., Walaszewski J., Pączek L. (red). Wydawnictwo Lekarskie PZWL. Warszawa. 2004;276.

10. Musielak M., Baum E.: Zabiegi transplantacyjne w perspektywie etycznej i społecznej. W: Transplantologia $\mathrm{w}$ zarysie. Dyszkiewicz W., Jemielity M., Wiktorowicz K. (red). Wydawnictwo Naukowe Akademii Medycznej w Poznaniu. Poznań. 2009;231-252.

11. Rowiński W., Wałaszewski J., Safjan D.: Problemy etyczno-obyczajowe przeszczepiania narządów. W: Transplantologia kliniczna. Rowiński W., Wałaszewski J., Pączek L (red). Wydawnictwo Lekarskie PZWL. Warszawa. 2004;307-312.

12. Kośmider-Cichomska A.: Postawy wobec przeszczepu narządów. Raport z badań. IPSOS. Warszawa. 2002;4-56.

13. Makruk-Studzińska M., Kowalska A.J., Jakubowska K.: Poziom wiedzy oraz opinie pielęgniarek na temat transplantacji organów. Medycyna Ogólna i Nauk o Zdrowiu. 2012;18,1,31-36. 
14. Pietruszka M., Falkowska-Pijagin.: Zjawisko transplantacji w opinii środowiska medycznego Szpitala Ogólnego w Kolnie. Zeszyty Naukowe nr 40. Łomża. 2009;21-36.

15. Dereczyński W.: Opinie o przeszczepianiu narządów. Komunikat z badań. Warszawa BS/161/2005;2-10.

16. Majchrowicz B., Sadowska L.: Problemy społeczne w świetle badań poziomu akceptacji transplantacji narządów i tkanek wśród mieszkańców Podkarpacia. Onkol. Pol. 2012;15,1,9-16.

17.http://drugieserce.jaw.pl/aktualnosci/?dar-zycia-i-jego-spolecznykontekst, 8, 28.02.2017, godz. 20.20.

18. Gorzkowicz B., Majewski W., Tracz E i wsp.: Opinia na temat dawstwa narządów wśród studentów uczelni wyższych Szczecina. Problemy Pielęgniarstwa. 2010;18,2,111-116.

19. Borkowska B., Falkowska-Pijagin E.: Zagadnienia transplantologii w Społecznej świadomości mieszkańców Ostrołęki. Zeszyty Naukowe nr 40. Łomża. 2009;5-20. 